\title{
SEROLOGICAL AND MOLECULAR STUDIES ON BTV IN SMALL RUMINANTS AT RISK AREA IN EGYPT POST- BT OUTBREAK IN LIBYA
}

\author{
HALLA E.K. EL BAHGY ${ }^{1}$; HALA K. ABDELMEGEED ${ }^{2}$ and MARAWAN A. MARAWAN ${ }^{3}$ \\ ${ }^{1}$ Hygiene and Veterinary Management Department, Faculty of Veterinary Medicine, Benha University, \\ Qualyobia, Egypt. \\ ${ }^{2}$ Animal Health Research Institute Virology Department, Giza, Egypt. \\ ${ }^{3}$ Infectious Diseases, Animal Medicine Department, Faculty of Veterinary Medicine, Benha University, \\ Qualyobia, Egypt.
}

Received: 29 September 2019; Accepted: 17 October 2019

\begin{abstract}
Bluetongue virus (BTV) is one of the most pressing trans-boundary viral diseases that cause worldwide great loss in the bovine industry either directly or indirectly worldwide. The current study was conducted to clarify the infection status of BTV at Marsa-Matruh (The West border with Libya) which is considered a high risk spot and an entrance gate for diseases in Egypt. Retrospective study on blue tongue outbreaks worldwide were carried out and the data were collected from the OIE website for pointing out the risky spots for blue tongue that may serve as a gateway of the disease to Egypt. Small ruminants in the Marsa-Matruh province were investigated in this study ( $n=555 ; 398$ sheep and 157 goats; aged between $6 \mathrm{~ms}$ to 3 years old) during a period from June to October 2017. Both serum and whole blood samples were collected, for detection of BTV antibodies and antigen using ELISA, while, BTV RNA was extracted from the whole blood samples for the detection of viral RNA. The results of retrospective study revealed the disease was absent in Egypt while it was reported in the border countries including Libya and in Palestinian during 2016. Moreover, serological examination demonstrated BTV specific antibodies at $54.5 \%$ and $30.5 \%$ for sheep and for goats, with an overall prevalence of $47.7 \%$. However, all serum samples tested negative for detection of bluetongue (BT) antigen. Further, RT-PCR confirmed the molecular findings showed that all blood samples tested negative for BT antigen. Since the BTV is capable of crossing Egypt borders through Libya, specially quarantine measures are mandatory at Marsa-Matruh province with careful animal screening for the evidence of infection/carrier status using suitable serological technique prior to importation.
\end{abstract}

Key words: Serological; molecular; risk factors; Marsa-Matruh; BTV.

\section{INTRODUCTION}

Bluetongue (BT) is an infectious, noncontagious, insect-born viral disease that affects sheep primarily, but other domestic and wild ruminant can be also affected (Kyriakis et al., 2015). It is considered a severe viral diseases of livestock that severely attacks them causing both direct and indirect losses. The direct losses include deaths, abortions, weight loss or reduced milk yield and meat efficiency in addition to the costs of preventive and control measures against the disease, while indirect losses are due to export limitations of live animals and their products from infected localities (Yavari et al., 2018).

Corresponding author: HALLA E.K. EL BAHGY

E-mail address: hala.mohamed@fvtm.bu.edu.eg.

Present address: Hygiene and Veterinary Management Department, Faculty of Veterinary Medicine, Benha University, Qualyobia, Egypt.
BT is caused by a double-stranded RNA virus (genus Orbivirus, family Reoviridae) that encodes the seven structural viral proteins (VP) namely from VP1 to VP7 (Russell and Gildenhuys 2018) and five non-structural proteins (NS1, NS2, NS3, NS3/A, NS4) with 27 distinct serotypes that have been identified and all have the ability to infect ruminants Based on the variation in the outer capsid proteins especially VP2 (Xie et al., 2018).

BT was firstly recorded in South Africa at the end of the $18^{\text {th }}$ century in South Africa, following the importation of susceptible Merino sheep from Europe. Later on the disease spread to most African countries including Egypt. Initially, it was known as "fever" or "epizootic catarrh", then as "malarial catarrhal fever of sheep" (Bréard et al., 2011) before being referred to as "Bluetongue" in (1905), due to the characteristic cyanotic tongues (Spreull 1905). In Europe, the first registration of BTV occurred in Cyprus in 1943 (Mellor et al., 2008). Further 
outbreaks were reported in Palestine (1943), Turkey (1944, 1946 \& 1947), and Israel (1949) (Gambles 1949; Komarov and Goldsmit 1951). BTV serotypes that invaded the Mediterranean basin after 1998 have the same origin from adjacent regions of either Africa or Asia (Mellor et al., 2008).

Egypt is a North African country extending from the Mediterranean Sea and is bounded westerly by Libya, easterly by Palestinian and Israel, and southerly by Sudan. Several studies have been carried out to clarify whether; Egypt is BT-free or not. The disease was firstly isolated on Vero cells and embryonated chicken eggs (ECE) in Egypt as early as 1974. It reappeared in 1980 with a more aggressive clinical presentation. After 10 years of dissipation, the virus was isolated from animal slaughterhouse samples in 1991, and the virus remained circulating until 2002 (Braverman et al., 2004). Furthermore, BTV was successfully isolated and propagated BTV from tissues samples of clinically infected sheep and goats during a 2012 outbreak in different governorates in Egypt (Zaher 2011). BTV was introduced to Libya across it's the southern border in 2015 and several BTV outbreaks were recorded in 2016 according to OIE reports (OIE 2016; Maan et al., 2012). Dependent on the current epidemiological data that revealed the occurrence of several BTV outbreaks in the border countries of Egypt especially Libya, the present study was conducted to clarify the infectious status of BTV in the border province of Libya (Marsa-Matruh) which is considered a high risk spot for introduction of the disease to Egypt.

\section{MATERIALS AND METHODS}

\section{Retrospective study}

Data on blue tongue outbreaks worldwide were collected from OIE Wahid web site during the period of study (January to December 2016) for identification the major localities of blue tongue outbreaks in the world and determination the risk factors for the disease transmission among localities and animals.

\footnotetext{
Animals

A total number of 555 animals were used in this study (398 from sheep and 157 from goats and aged between $6 \mathrm{~m}$ to 3 years old). These animals were from different herds in Marsa-Matruh province (which is considered a high-risk spot and an entrance gate for diseases in Egypt, Fig. 1) during a period from June to October 2017. The vaccination history of the animals under investigation was unrecorded.

\section{Samples}

Blood samples were collected and divided into two portions, one part was collected using via plain vacuum tube without anticoagulant and then left overnight in the refrigerator, centrifuged at $3000 \mathrm{rpm}$
}

for 5 minutes at $4{ }^{\circ} \mathrm{C}$ to obtain serum for detection of BTV specific antibodies and antigen (Ag) by using ELISA. The other portion was collected as whole blood using a vacuum tube containing EDTA for molecular detection of BTV using RT-PCR followed by RNA extraction. Twenty whole blood samples were used from ELISA seropositive samples show high $\mathrm{Ab}$ titer, including 12 sheep and 8 goats.

\section{Serological detection of BTV specific antibodies using Competitive ELISA}

Commercial ID. Vet (France) BTV Compact ELISA kit was used for the detection of BTV specific antibodies $(\mathrm{Ab})$ against VP7 protein in the collected sera samples according to manufacturer instructions. This assay is based on a blocking immune enzymatic assay where the solid phase is plates coated with monoclonal VP7 protein of BTV (Chand et al., 2017).

\section{Serological detection of BTV antigen detection using the sandwich ELISA}

Antigen detection of BTV (VP7 protein) was achieved using the commercial Bluetongue virus antigen kit/serum plus, INGEZIM BTV DAS, (Spain) of $\mathrm{Ag} /$ serum plus ELISA test according to the manufacturer instructions (Chand et al., 2017).

\section{Molecular detection of BTV}

The viral RNA was extracted from whole blood samples using the QIAamp viral RNA Mini kit (Qiagen, GmbH, Germany) according to the manufacturer instruction to obtain BT RNA template. The used primers were: Forward primer 5'TCGCTGCCATGCTATCCG -3'and Reverse primer 5'- CGTACGATGCGAATGCAG -3'. The amplicon was $251 \mathrm{bp}$ targeting BTV VP7 protein. The amplification reaction was performed using thermalcycler (Life ECO, China) in the following cycles: one cycle of reverse transcription at $50{ }^{\circ} \mathrm{C}$ for $30 \mathrm{~min}$, one cycle of initial denaturation step at $95^{\circ} \mathrm{C}$ for 5 min, followed by 35 cycles of $94^{\circ} \mathrm{C}$ for $30 \mathrm{sec}$. (denaturation), $52^{\circ} \mathrm{C}$ for $30 \mathrm{sec}$. (annealing) and $72^{\circ} \mathrm{C}$ for $30 \mathrm{sec}$. (extension). A final extension step was one cycle at $72^{\circ} \mathrm{C}$ for $10 \mathrm{~min}$ (Akita et al., 1992). The PCR products were separated by electrophoresis on $1.5 \%$ agarose gel (Applichem, GmbH, Germany) in $1 \mathrm{x}$ TBE buffer at room temperature using gradients of $5 \mathrm{~V} / \mathrm{cm}$. A total of $15 \mu \mathrm{l}$ product was loaded in each gel slot for gel analysis. A 100 bp DNA ladder was used as a loading control (Qiagen, GmbH, Germany). The gel was visualized by a gel documentation system (Alpha Innotech, Biometra) and the data were analyzed through computer software.

\section{Statistical analysis}

The incidence rate of seropositivity in sheep and goat were statistically analyzed with $C h i$-square test using SPSS (Ver. 23). $P$ value was set at $<0.05$ to define statistical significance. 


\section{RESULTS}

The retrospective study revealed that several BTV outbreaks were distributed in different localities worldwide including Libya in Africa, Palestinian in Asia and Italy, Serbia and France in Europe (Fig. 1), moreover the infection recorded the highest rates among sheep flocks rather than others animal species during 2016 outbreaks (Table 1). Also, it was noticed that the incidence and case fatality rates of BTV were the highest in sheep and were the lowest in the cattle (Fig. 2). Surprisingly, the disease was absent in Egypt while it was reported in the border country of Egypt including Libya so Marsa-Matroh province act as risk area for BT virus circulation (Fig. 3).

The findings of ELISA for the detection of BTV specific antibodies exhibited that the percentage of BTV antibodies in sera was significantly $(P>0.0001)$ higher in sheep than goat species $(54.5 \%$ and $30.5 \%$, respectively) with an overall prevalence $47.7 \%$ (Table 2). In contrast, the ELISA failed to detect the BTV antigen in all tested samples from both species.

The BTV VP7 protein was not detected in the all blood samples using RT-PCR and all samples were tested negative with the absence of PCR band at the target size $251 \mathrm{bp}$ after gel electrophoresis (Fig. 4).

Table 1: Incidence and case fatality rates of Blue tongue disease in some epidemic country during 2016.

\begin{tabular}{|c|c|c|c|c|c|c|c|}
\hline & Country & species & $\begin{array}{c}\text { No. of } \\
\text { susceptible animals }\end{array}$ & $\begin{array}{l}\text { No. of } \\
\text { cases }\end{array}$ & $\begin{array}{l}\text { No. of } \\
\text { deaths }\end{array}$ & $\begin{array}{l}\text { Incidence } \\
\text { rate }\end{array}$ & $\begin{array}{c}\text { Case } \\
\text { fatality }\end{array}$ \\
\hline Africa & Libya & Sheep & 2444 & 220 & 155 & $9.0 \%$ & $70.45 \%$ \\
\hline Asia & Palestinian & sheep & 1958 & 140 & 30 & $7.15 \%$ & $21.42 \%$ \\
\hline \multirow{9}{*}{ Europa } & \multirow{3}{*}{ Italy } & Cattle & 46466 & 2580 & 13 & $5.5 \%$ & $0.5 \%$ \\
\hline & & Sheep & 44541 & 2758 & 977 & $6.19 \%$ & $35.42 \%$ \\
\hline & & Goats & 1838 & 17 & 3 & $0.92 \%$ & $17.6 \%$ \\
\hline & \multirow{3}{*}{ Serbia } & Cattle & 1224 & 69 & 4 & $5.6 \%$ & $5.79 \%$ \\
\hline & & Sheep & 57068 & 699 & 202 & $1.22 \%$ & $28.89 \%$ \\
\hline & & Goats & 14 & 1 & - & $7.14 \%$ & $0 \%$ \\
\hline & \multirow{3}{*}{ France } & Cattle & 577397 & 220 & 6 & $0.03 \%$ & $2.72 \%$ \\
\hline & & Sheep & 12431 & 326 & 44 & $2.62 \%$ & $13.49 \%$ \\
\hline & & Goats & 960 & 10 & 1 & $1.04 \%$ & $10 \%$ \\
\hline \multirow{3}{*}{\multicolumn{2}{|c|}{ Total }} & Cattle & 625087 & 2869 & 23 & $0.45 \%$ & $0.80 \%$ \\
\hline & & Sheep & 118442 & 4143 & 1408 & $3.49 \%$ & $33.98 \%$ \\
\hline & & Goats & 2812 & 28 & 4 & $0.99 \%$ & $14.28 \%$ \\
\hline
\end{tabular}

This data collected from Wahid OIE during 2016 outbreaks.

Table 2: Seroprevalence of bluetongue disease among sheep and goat at Marsa Matruh province, Egypt.

\begin{tabular}{cccc}
\hline Species & No. of animals & No. of positive & Percent \\
\hline Sheep & 398 & 217 & $54.5 \% *$ \\
\hline Goats & 157 & 48 & $30.5 \%$ \\
\hline Total & 555 & 265 & $47.7 \%$ \\
\hline
\end{tabular}

\footnotetext{
* The Chi-square statistic with Yates correction is 24.93. The p-value is 0.000001. The incidence of BT was significant at $\mathrm{p}<.05$.
} 


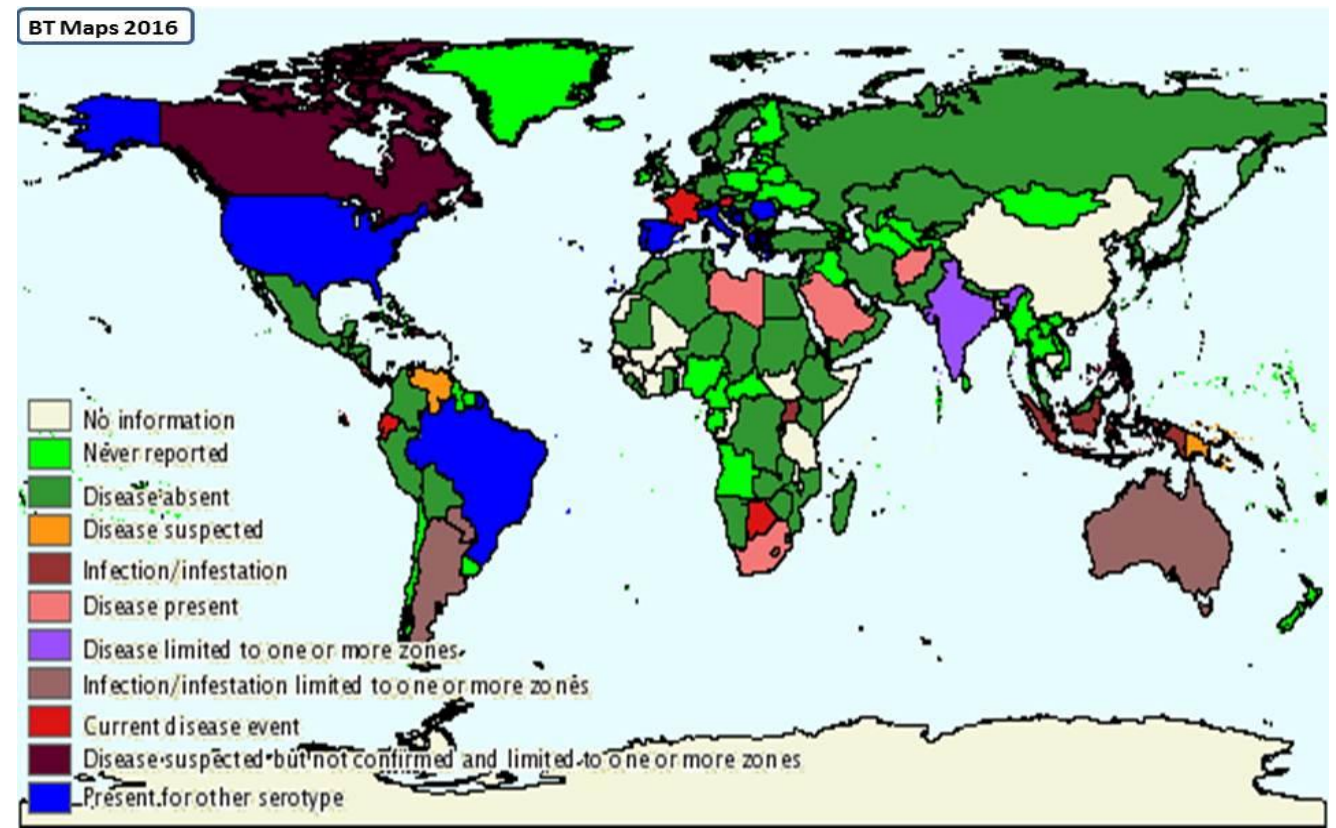

Fig. 1. Blue tongue virus outbreaks worldwide during 2016 www.oie.int/wahis/public

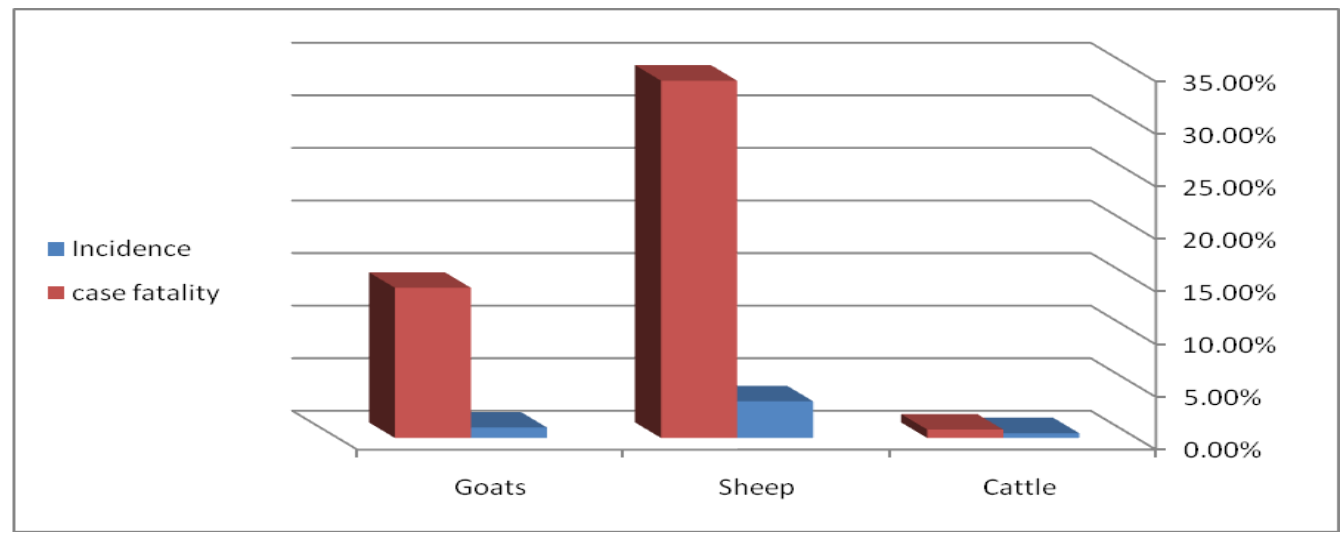

Fig.2. Incidence and case fatality rates of blue tongue disease in different species at epidemic country in 2016.

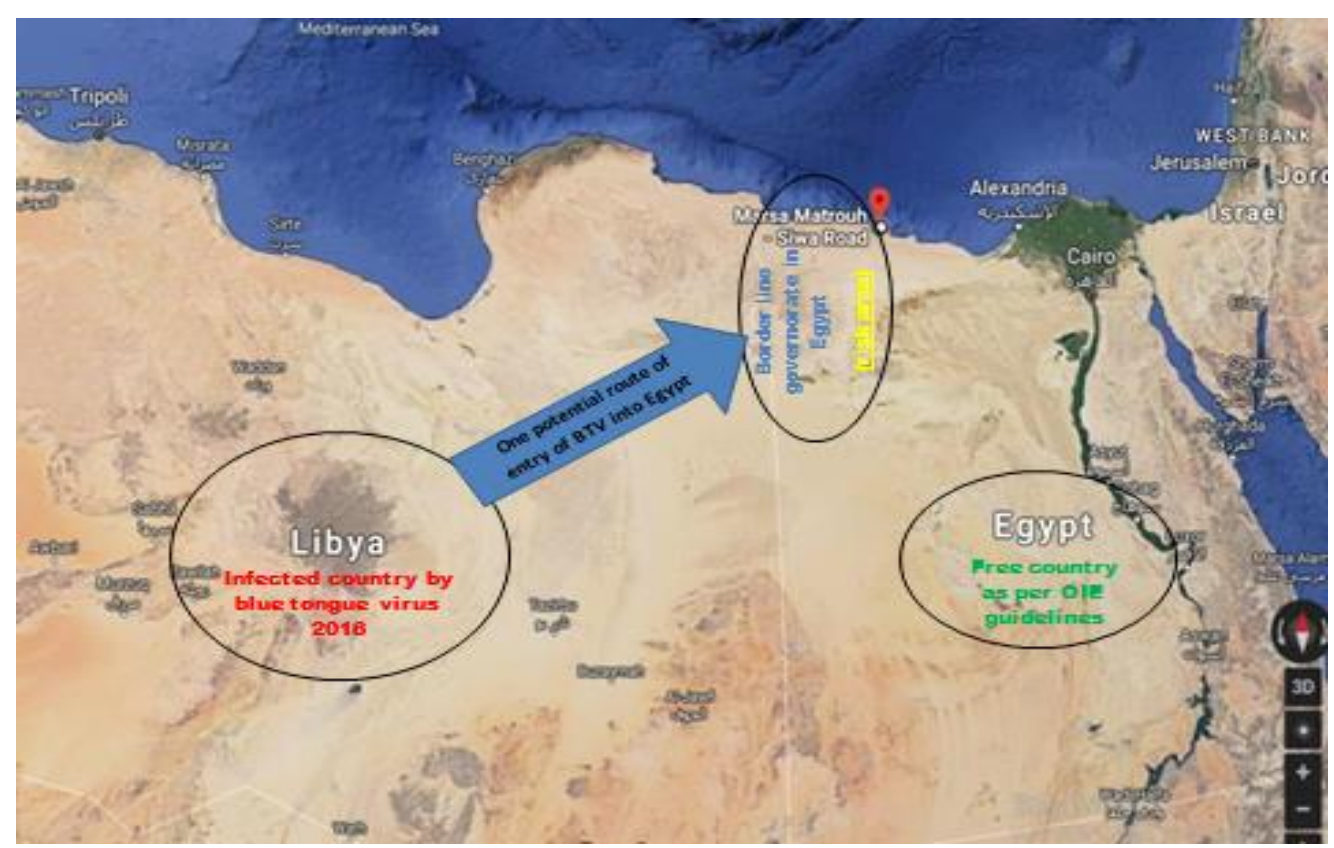

Fig. 3 Risk area and one potential portal of entry of BTV circulating antibodies in Egypt. 


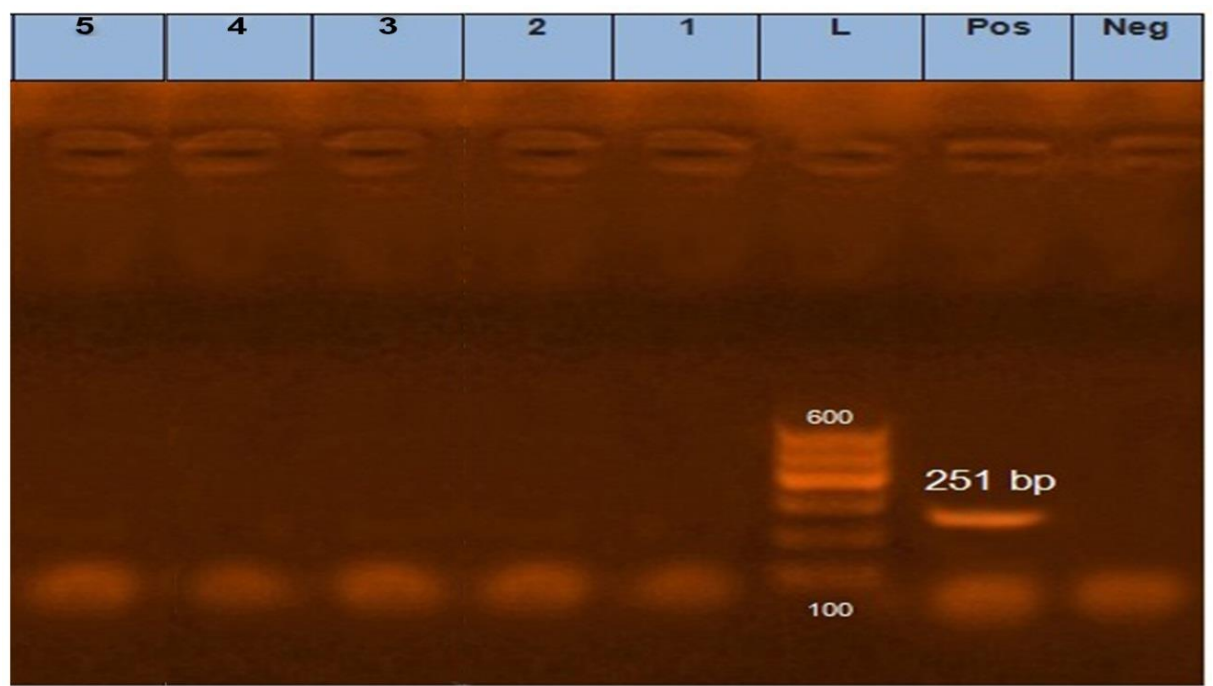

Fig. 4: Results of PCR agarose electrophoresis. L is 100 bp DNA ladder, Pos is control positive, Neg is control negative and the lanes from 1 to 5 are the examined samples. All the examined samples showed no positive bands at the target size (251 bp).

\section{DISCUSSION}

BTV is a highly infectious non-contagious disease of ruminants and is listed among the transboundary animal disease (TADs) that can spread rapidly across countries borders (Sohail et al., 2019; Calistri et al., 2007). Because of its economic importance in addition to high morbidity and mortality rate, BT is recognized as a notifiable disease by OIE for the establishment of early diagnosis of the disease and subsequently providing both early warning and blocking of the possible outbreaks (Mellor 2002). The epidemiological obtained from OIE website (http://www.oie.int/wahis/public) informed that BT outbreaks were distributed in different localities worldwide, including Libya in Africa and Palestinian in Asia. Moreover, the highest incidence and case fatality were recorded among sheep flocks more than other animal species during 2016 outbreaks (OIE 2016). Surprisingly, the disease was absent in Egypt (OIE 2016) while it was reported in the border countries including Libya, designating Marsa-Matruh province (the frontier between Egypt and Libya) acts as a risk area for the skulking of BTV.

The results of the current study presented a higher BTV seroprevalence among the sheep than goats at $54.5 \%$ and $30.5 \%$, respectively. Although goat had a minimum clinical manifestation of BTV with pertaining a lower antibodies titer than sheep, it may be a potential source of infection to other susceptible animals (Yilma and Mekonnen 2015). The present data is consistent with the worldwide observational study in 2016 of BT outbreaks which recorded the highest prevalence of BTV infection in sheep rather than other species. This elucidates that sheep are more susceptible to BT than other animals, and acts as an indicator host showing distinct clinical signs including death (Yilma and Mekonnen 2015). The seropositive response against BTV may develop for two main reasons: (i) vaccination or infection of the animals that illegally imported from Libya, or (ii) the presence of a circulating BTV in relation to virulence species- resistance (Avci et al., 2014). The legal importation of animals is similarly damaging, if these animals were infected. It serves as a conduit for pathogen introduction, establishment, and spread (Hueston et al., 2011; Karesh et al., 2012). Further, BTV virulence plays a crucial role in the clinical picture of the disease in which a low viral virulence can induce a protective immune response without showing any clinical signs. Moreover the viral strain may be adapted to the Egyptian domestic sheep and goats (Lundervold et al., 2004).

On the other hand, no BTV antigen was detected in all serum samples under examination using Ag detection ELISA and all whole blood samples were tested negative using RT-PCR as well. These findings may be attributed to old infection with the clearance of the virus from the animal body likewise other viral infections (Azimi et al., 2011) or due to the influence of breed. Clinical recognition of the disease was verified in the presence of highly susceptible European breeds of sheep (Mertens et al., 2008). Accordingly, the native Egyptian breeds may have a resistance gene against BTV.

Although this study did not confirm the existence of the BTV, the presence of seropositive animals in Marsa-Matruh province serves as an early alarm for the possible introduction of BTV outbreaks to Egypt through the borders of infected localities. Therefore, special measures should be taken during animal importation and disparagement of illegal animal movement should be adopted parallel with the prevalence of BT outbreaks in border countries like Libya. 


\section{CONCLUSION}

BTV was recorded in Libya, a border country of Marsa-Matruh province, Egypt. Due to the presence of high seroprevalence of BTV in small ruminants in Marsa-Matruh, this indicates that Libya may serves as a source for passage of the disease to Egypt. Accordingly, (i) quarantine measures should be established on the country border and (ii) the moved/imported animals must be screened for the evidence of disease using suitable diagnostic techniques.

\section{ABBREVIATIONS}

BHK: Baby Hamester Kidney Cells; BTV: Blue tongue virus; C-ELISA: Competitive Enzyme Linked Immune Sorbent Assay; ECE: Embryonated Chicken Eggs; NS: non-structureprotein; OIE: World Organization of Animal Health; RT-PCR: Reverse Transcriptase Polymerase Chain Reaction; TADs: Transboundary Animal Diseases; VP: structure protein

\section{ACKNOWLEDGMENT}

The authors gratefully acknowledge all farmers in the Marsa-Matruh governorate who allowed for us to collect the samples and the Animal Health Research Institute, Agriculture Research Center, Doki, Giza, Egypt.

\section{AUTHORS' CONTRIBUTIONS}

HEKE, HKA and MAM designed the concept for this research and scientific paper. HEKE collected and analyzed the retrospective data. HEKE and HKA visited the risk area, collected all blood samples and survey data. HEKE, HKA and MAM examined the samples and analyzed data. All authors participated in manuscript's draft and revision. All authors have read and approved the final manuscript.

\section{ETHICS APPROVAL AND CONSENT TO PARTICIPATE}

The samples were collected under national and international standard biosafety conditions and ethics. Also, the study designs and collection of samples were approved by Animal Health Research Institute, Agriculture Research Center, Doki, Giza, Egypt (Code No. 11429).

\section{REFERENCES}

Akita, G.Y; Chinsangaram, J.; Osburn, B.I.; Ianconescu, M. and Kaufman, R. (1992): "Detection of bluetongue virus serogroup by polymerase chain reaction". J Vet Diagn Invest, 4(4):400-405.

Avci, O.; Orhan, Y.; Oya, B.; Mehmet, K.; Sibel, Y. and Atilla S. (2014): "Detection of antibodies against Blue tongue virus in yaks (Bos grunniens) in Issyk kul, first report". J Anim Plant Sci, 24(4): 1220-1223.

Azimi, S.; Mahravani, H.; Jeirani, F. and Shoshtari A. (2011): "Appling real time RT-PCR for bluetongue virus detection in Iran". Arch Razi Inst, 66(2): 75-80.

Braverman, Y.; Baylis, M.; Tatem, A.; Rogers, D.; Mellor, P. and Purse B. (2004): "What factors determine when epidemics occur in the Mediterranean? Prediction of disease risk through time by climate-driven models of the temporal distribution of outbreaks in Israel". Vet Ital. 40(3): 235-242.

Bréard, E.; Belbis, G.; Hamers, C.; Moulin, V.; Lilin, T.; Moreau, F.; Millemann, Y.; Montange, C.; Sailleau, C. and Durand, B. (2011): Evaluation of humoral response and protective efficacy of two inactivated vaccines against bluetongue virus after vaccination of goats. Vaccine, 29(13): 2495-2502.

Calistri, P.; Savini, L.; Ippoliti, C. and Conte, A. (2007): Web-based geographic information system tools and international surveillance network for bluetongue in the Balkans and south-east Europe (East-BTNet). Vet Ital, 43(3): 739-744.

Chand, K.; Biswas, S.K.; Pandey, A.B.; Saxena, A.; Tewari, N. and Mondal, B. (2017): A competitive ELISA for detection of group specific antibody to bluetongue virus using anti-core antibody. Biologicals. 46:168-171.

Gambles, R. (1949): Bluetongue of sheep in Cyprus. Comp Clin Path. 1949;59: 176-190.

Hueston, W.; Travis, D. and van Klink, E. (2011): Optimising import risk mitigation: Anticipating the unintended consequences and competing risks of informal trade. Rev Sci Tech Off int Epiz, 30(1): 309- 316.

Karesh, W.; Smith, M. and Asmüssen, M. (2012): The unregulated and informal trade in wildlife: Implications for biodiversity and health. Pages 51-57. Compendium of the OIE Global Conference on Wildlife. OIE (World Organisation for Animal Health), Paris, France.

Komarov, A. and Goldsmit L. A (1951): disease similar to bluetongue in cattle and sheep in Israel. Isr J Vet Med (Refuah vet), 8: 96-100.

Kyriakis, C.; Billinis, C.; Papadopoulos, E.; Vasileiou, N.; Athanasiou, L. and Fthenakis, G. (2015): Bluetongue in small ruminants: An opinionated review, with a brief appraisal of the 2014 outbreak of the disease in Greece and the south-east Europe. Vet Microbiol, 181(12): 66-74. 
Lundervold, M.; Milner-Gulland, E.; O'callaghan, C.; Hamblin, C.; Corteyn, A. and Macmillan, A. (2004): A serological survey of ruminant livestock in Kazakhstan during post-Soviet transitions in farming and disease control. Acta Vet Scand, 45(4): 211-224.

Maan, N.S.; Maan, S.; Belaganahalli, M.N.; Ostlund, E.N.; Johnson, D.J.; Nomikou, K. and Mertens, P.P. (2012): Identification and differentiation of the twenty six bluetongue virus serotypes by RT-PCR amplification of the serotype-specific genome segment 2. PloS One.7(2): e32601.

Mellor, P. and Wittmann, E. (2002): Bluetongue virus in the Mediterranean Basin 1998-2001. Vet J, 164(1):20-37.

Mellor, P.S.; Carpenter, S.; Harrup, L.; Baylis, M. and Mertens, P.P. (2008): Bluetongue in Europe and the Mediterranean Basin: history of occurrence prior to 2006. Prev Vet Med, 87(1-2): 4-20.

Mertens, P.; Baylis, M. and Mellor, P.(2008): Bluetongue. Elsevier; Academic Press. 2008; $1^{\text {st }}$ edition: 506.

OIE, (2016): World Animal Health Information Database (WAHID). Available at http://www.oie.int/wahis_2/public/wahid.php/ Wahidhome/Home/indexcontent/newlang/en. (Access date 09 September 2016).

Russell, B.L. and Gildenhuys, S. (2018): Solubilisation and purification of recombinant bluetongue virus VP7 expressed in a bacterial system. Protein Expr Purif, 147: 85-93.

Sohail, T.; Yaqub, T.; Abbas, T.; Rabbani, M.; Nazir, J.; Maqbool, S.M.; Yaqub, S.; Habib, M.; Mukhtar, N. and Shahbaz, M. (2019): Seroprevalence of Bluetongue virus in small and large ruminants in Punjab province, Pakistan. Acta Trop. 189: 22-29.

Spreull, J.(1905): Malarial catarrhal fever (bluetongue) of sheep in South Africa. J Comp Pathol Ther. 18: 321-337.

Xie, S.; Shi, Y.; Gong, R.; Cui, W.; Jiang, Y.; Liu, M.; Wang, L.; Zhou, H.; Qiao, X. and Li, Y. (2018): Identification of antigenic epitopes of monoclonal antibodies against the VP2 protein of the 25 serotype of bluetongue virus. Vet Microbiol, 219: 136-143.

Yavari, M.; Gharekhani, J. and Mohammadzadeh, A. (2018): Bluetongue virus seropositivity and some risk factors affecting bluetongue virus infection in sheep flocks. Comp Clin Path, 27(4): 1017-1022.

Yilma, M. and Mekonnen, M. (2015): Competitive enzyme linked immuno-sorbent assay (cELISA) based sero-prevalence of bluetongue virus (BTV) on small ruminants in selected areas of Wolyita, Southern Ethiopia. Virol Mycol, 4(2): 148-151.

Zaher, K.S. (2012): Bluetongue Infection in Small Ruminants in Egypt. AJAD. 1(3): 21-26.

\title{
دراسات سيرولوجية وجزيئية على فيروس اللسان الأزرق في المجترات الصغيرة المعرضة للخطر في مصر بعد اندلاع اللسان الازرق في ليبيا

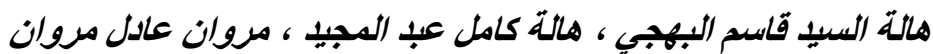

E-mail: hala.mohamed@fvtm.bu.edu.eg. Assiut University web-site: www.aun.edu.eg

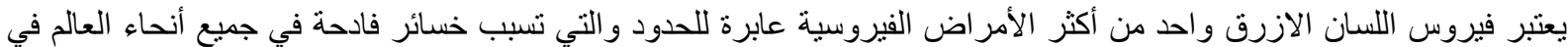

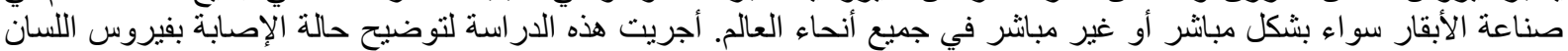

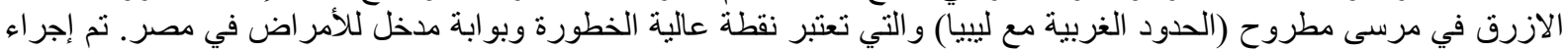

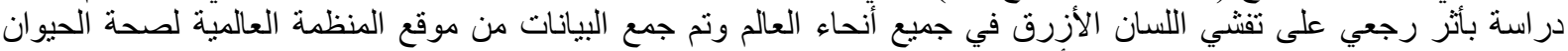

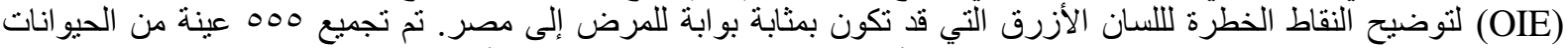

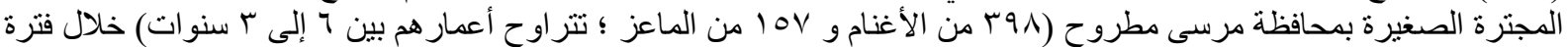

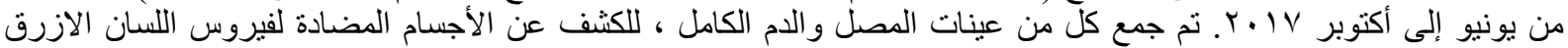

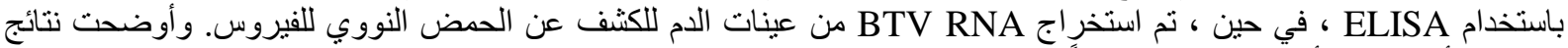

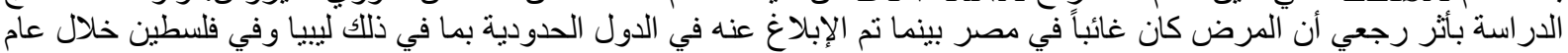

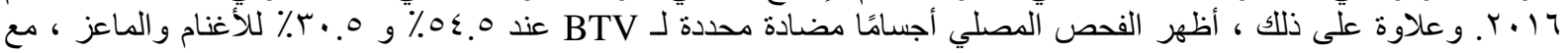

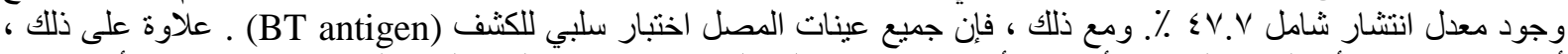

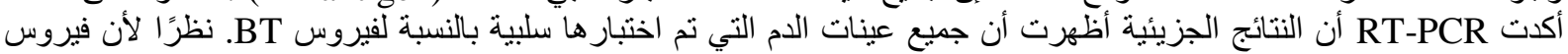

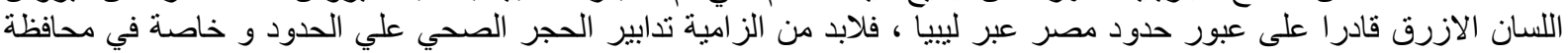
مرسى مطروح مع فحص دقيق للحيو انات لإثبات وجود حالة إصابة / او حامل باستخدام تقنية مصلية مناسبة قبل الإسير الاستير اد.
\end{abstract}

